\title{
PENGARUH KEPEMIMPINAN TRANSFORMASIONAL, ORGANISASI PEMBELAJARAN DAN KOMITMEN ORGANISASI TERHADAP KINERJA DOSEN DI UNIVERSITAS PAMULANG, TANGERANG SELATAN
}

\author{
Surasni $^{*}$ \\ niniek.yoga@yahoo.com
}

\begin{abstract}
ABSTRAK
PENGARUH KEPEMIMPINAN TRANSFORMASIONAL, ORGANISASI PEMBELAJARAN DAN KOMITMEN ORGANISASI TERHADAP KINERJA DOSEN DI UNIVERSITAS PAMULANG, TANGERANG SELATAN. Penelitian ini bertujuan untuk memperoleh data nyata dan menganalisis tentang pengaruh kepemimpinan transformasional, organisasi pembelajaran, dan komitmen organisasi terhadap kinerja dosen. Survey dilakukan di Universitas Pamulang Tangerang Selatan.Metode yang di gunakan adalah dengan cara survey. Dengan menggunakan sistem Random Sampling, 109 dosen.Data di analisis dengan menggunakan analisis-path. Setelah semua variabel di masukkan ke dalam Korelasi Matrik. Populasi penelitian ini adalah dosen-dosen Universitas Pamulang, Tangerang Selatan. Data diperoleh dari kuesioner dan kemudian di analisis dengan Statistik Diskripsi dan statistik Inferensional. Hasil dalam penelitian tersebut menunjukkan bahwa kinerja berpengaruh positif langsung dengan kepemimpinan transformasional, organisasi pembelajaran dan komitmen organisasi. Dalam penelitian tersebut juga di temukan bahwa komitmen organisasi berpengaruh positif langsung dengan kepemimpinan transformasional dan Organisasi pembelajaran . Berdasarkan penemuan penelitian tersebut dapat di simpulkan bahwa terjadi perubahan kinerja dosen yang di pengaruhi oleh kepemimpinan transformasional organisasi pembelajaran dan komitmen organisasi dapat di gunakan untuk mengembangkan strategi rencana sumber daya manusia.
\end{abstract}

Kata kunci : Kepemimpinan transformasional, organisasi pembelajaran, komitmen organisasi, dan kinerja.

\begin{abstract}
THE EFFECT OF TRANSFORMATIONAL LEADERSHIP, LEARNING ORGANIZATIONAL, AND ORGANIZATION COMMITMENT TOWARDS LECTURERS' JOB PERFORMANCE AT THE UNIVERSITY OF PAMULANG,SOUTH TANGERANG. The objective of this research is to gain the emperical data and to analyze about the effect of transformational leadership, learning organizational, and organization commitment towards the job performances. The research was conducted at the University of Pamulang South Tangerang. Research method is survey technique. By using cluster-simple random sampling, 109 lectures. which the data had been analysed by path analyze, after all variables were put into a correlational matrix. The research population was lecturers the University of Pamulang South Tangerang. The data were obtained from questionnaire were then analyzed using description statistics and inferensial statistical. The result of the research showed that job performance was positive direct effect by transformational leadership, learning organizational, and organization commitment. It was also found that organization commitment was positive direct effect by transformational leadership and learning organizational positive direct effect. Based on those findings it could be concluded that any change or variation which occurred at job performances might have been effected by transformational leadership, learning organizational and organization commitment. Therefore, in job performances, transformational leadership, learning organizational, and organization commitment can use into strategic planning of human resources development.
\end{abstract}

Keywords: Transformational leadership, learning organizational, Organization commitment, and job performance.

*) Dosen Universitas Pamulang (UNPAM) 


\section{PENDAHULUAN}

\section{A. Latar Belakang Masalah}

Pendidikan menjadi tumpuan dan harapan negara serta bangsa Indonesia untuk dapat sejajar mutunya dengan negara dan bangsa lain. Kemajuan bangsa Indonesia dan negara lain tidak bisa dicapai tanpa didukung oleh sistem pendidikan yang bermutu. Sistem pendidikan bermutu akan berkontribusi besar terhadap lahirnya sumber daya manusia bermutu yang dapat meningkatkan kemandirian dan berkompeten dalam kehidupan.

Pendidikan di Indonesia, yang paling berperan untuk meningkatkan kinerja pegawai salah satunya lulusan sarjana. Perguruan Tinggi sebagai tempat lahirnya para sarjana tergantung kepada kepiawaian kinerja dosen. Dosen saat mengajar harus terampil. Dalam berorganisasi dosen bisa bertanggung jawab, baik pada level Universitas maupun pada level Fakultas.

Beberapa alasan yang dapat dikemukakan agar menjadi dosen profesional yaitu: Pertama, dosen harus berperan mempromosikan keunggulan institusi pada masyarakat; Kedua, dosen dapat mendisain sistem recruitment staf akademik dan mahasiswa baru; Ketiga, dosen dapat memberikan inovasi dan motivasi kepada mahasiswa sehingga ketua program studi dapat mengembangkan program studinya; Keempat, dosen dapat memperbaiki atmosfir akademik dan kondisi kerja, serta Kelima, dosen menyatukan kepentingan dan minat yang beragam dalam proses belajar mengajar mahasiswa menjadi lulusan yang bermutu saat terjun ke masyarakat.

Dosen selaku tenaga pengajar di jenjang pendidikan tinggi merupakan unsur penunjang program pendidikan yang akan mempengaruhi proses pembelajaran. Selain mengajar juga memiliki fungsi paling strategis untuk meningkatkan kualitas sumber daya lulusan. Dosen dituntut bekerja secara profesional diantaranya memiliki kesadaran untuk terus-menerus meningkatkan kinerja serta kualitas kerjanya. Kualitas dosen dan lulusan ini penting karena berpengaruh terhadap kelangsungan hidup dan mutu Perguruan Tinggi. Namun permasalahannya adalah kinerja dosen dalam melaksanakan tugas Tri Dharma Perguruan Tinggi belumlah optimal. Belum optimal banyak dipengaruhi beberapa faktor diantaranya sarana prasarana penunjang kerja dosen belum optimal, kompensasi yang belum memadai dan jaminan masa depan kesempatan bersekolah beasiswa susah mendapatkannya.

S.Gopinathan salah satu Senior Consultant Putera Sampoerna School of Education, mengatakan bahwa: berbagai persoalan yang ada di seputar pendidikan yang tidak kunjung jelas, karena minimnya penelitian kependidikan. Selama ini sebagian besar tenaga pendidik hanya tertuju dan memusatkan perhatian pada peningkatan kemampuan mengajar saja. Minimnya penelitian yang dilakukan oleh dosen berimbas pada aktivitas ilmiah mahasiswanya.

Belum optimalnya lulusan Perguruan Tinggi terserap dalam pasar kerja terutama disebabkan oleh faktor eksternal dan faktor internal. Faktor eksternal berkaitan dengan krisis ekonomi yang belum membaik (recovery) ini akan berdampak terhadap pertumbuhan ekonomi dan kemampuan industri dan dunia usaha dalam menyerap tenaga kerja. Sementara faktor internal berkaitan dengan kurikulum yang belum sesuai untuk keperluan industri dan dunia usaha. 
Kelemahan lulusan sarjana di perguruan tinggi baik negeri maupun swasta dalam bersaing di pasar tenaga kerja adalah karena rendahnya kecakapan dan keahlian, termasuk rendahnya kompetensi para lulusan sarjana. Hal ini dikarenakan kurangnya kinerja, komunikasi, berorganisasi dan pengendalian diri..

Daniel H. Kim seperti dikutip oleh Munir mendefinisikan pembelajaran sebagai proses untuk mendapatkan pengetahuan atau keterampilan. Definisi ini mencakup dua hal utama, yaitu : 1) know-how atau pengetahuan tentang bagaimana cara membuat sesuatu yang pada akhirnya akan menghasilkan kemampuan fisik untuk menghasilkan suatu tindakan tertentu; dan 2) know-why atau pengetahuan yang menjawab pertanyaan tentang mengapa sesuatu itu demikian adanya. Proses mendapatkan know-why ini akan menghasilkan kemampuan untuk mengartikulasikan pemahaman konseptual dari suatu pengalaman tertentu. Kedua konsep pembelajaran ini, yaitu apa yang dipelajari, yaitu (know-how) dan bagaimana manusia memahami dan menerapkan apa yang telah dipelajarinya (know-why), dalam prakteknya merupakan suatu kesatuan yang penting. Munir menekankan pada pentingnya peningkatan kapasitas manusia dalam pembelajaran sebagai proses peningkatan kapasitas manusia untuk melakukan tindakan yang efektif.

Persoalan yang berhubungan dengan manusia seperti komitmen, kelompok kerja, keterampilan dan kompetensi menjadi inti dari kinerja pegawai. Dalam organisasi, ada tiga hal utama yang harus diupayakan untuk membuat organisasi sigap terhadap perubahan, yaitu 1) menggantikan sistem keyakinan organisasi terdiri dari visi dan nilai-nilai yang dianut organisasi 2) membangun pendorong kinerja seperti target, hasil usaha, dan 3) meyakinkan bahwa semua pekerjaan telah terintegrasi dengan baik.

Richard L. Daft dalam bukunya New Era of Management menyatakan bahwa kehidupan manusia dewasa ini berada pada turbulent times, suatu periode yang penuh pergolakan dalam boundariless world, dunia tak terbatas juga dalam dunia bisnis.

Turbulent times in business tidak hanya ditandai oleh luas dan keragaman persaingan, tetapi makin tajamnya keganasan persaingan pada tingkat dunia. Salah satu syarat mutlak yang harus dipahami dan diimplementasikan secara jujur dan konsisten ialah menjaga dan meyakinkan kepada para pelanggan, bahwa kinerja seorang pendidik telah memenuhi proses yang ditentukan oleh Lembaga Internasional yang kredibel dan telah didokumentasikan serta diimplementasikan secara konsisten. Lembaga termaksud adalah International Organization for Standardization (ISO). Salah satu bentuk yang dihasilkan oleh lembaga tersebut adalah ISO 9000. Dengan adanya ISO 9000 kinerja pegawai dapat selalu dipantau dan dinilai apakah berkembang atau menurun. ISO 9000 selalu menilai tiap periode tertentu. Berkembangnya tenaga kerja dari tahun ke tahun setiap periode semakin meningkat hal ini disebabkan Indonesia adalah salah satu negara dengan penduduk terpadat.

Lulusan sekolah kejuruan dan menengah mengalami kesulitan menemukan pekerjaan di pasar kerja nasional. Hampir setengah dari jumlah total tenaga kerja di Indonesia hanya memiliki ijazah sekolah dasar saja. Semakin tinggi pendidikannya semakin rendah partisipasinya dalam kekuatan tenaga kerja Indonesia. Meskipun demikian dalam beberapa tahun terakhir terlihat adanya perubahan yang signifikan yaitu pemegang ijazah pendidikan tinggi semakin besar, dan pangsa pemegang ijazah 
JURNAL ILMIAH ILMU MANAJEMEN

pendidikan dasar semakin berkurang. Dibawah ini adalah tabel penganguran usia muda di Indonesia.

Tabel 1. : Pengangguran Usia Muda

\begin{tabular}{|l|l|l|l|l|l|l|}
\hline & 2006 & $\mathbf{2 0 0 7}$ & $\mathbf{2 0 0 8}$ & $\mathbf{2 0 0 9}$ & $\mathbf{2 0 1 0}$ & $\mathbf{2 0 1 1}$ \\
\hline $\begin{array}{l}\text { Pengangguran Muda } \\
\text { Pria } \\
\text { (persentase tenaga kerja } \\
\text { pria 15-24 tahun) }\end{array}$ & 27.7 & 23.8 & 21.8 & 21.6 & 21.1 & 19.3 \\
\hline $\begin{array}{l}\text { Pengangguran Muda } \\
\text { Wanita } \\
\text { (persentase tenaga kerja } \\
\text { wanita 15-24 tahun) }\end{array}$ & 34.3 & 27.3 & 25.5 & 23.0 & 22.0 & 21.0 \\
\hline
\end{tabular}

Sumber: Bank Dunia

Dari data diatas dapat dilihat bahwa tenaga kerja Indonesia lebih banyak yang berpendidikan lulusan SD dibandingkan dengan lulusan sarjana. Pengangguran usia muda dari data mengalami penurunan dari tahun ke tahun. Pemerintah terus berupaya agar tenaga kerja di Indonesia menjadi SDM yang potensial dan saat terjun ke masyarakat menjadi tenaga kerja yang melakukan kerja dengan hasil yang memuaskan.

Secara tidak langsung akan menciptakan suasana kerja para dosen mempunyai kompetensi yang tinggi dalam melakukan pekerjaan mendidik para mahasiswa menjadi lulusan terbaik. Disamping itu, perguruan tinggi juga dapat mengembangkan organisasi yang ada didalam lingkungan secara efektif bagi para dosen-dosennya dengan membentuk kelompok kerja. Dari kelompok kerja tersebut diharapkan ada inovasi baru yang muncul dari dosen. Kompetensi dosen juga menjadi tinggi dalam kelompok kerja tersebut. Adapun dosen secara inovatif dan kreatif dan secara terus menerus memupuk ciri-ciri kelompok kerja yang sehat, yaitu : 1) kejelasan tujuan; 2) inovatif; 3) komunikasi yang sehat dan 4) pengambilan keputusan dengan tepat. Momen yang tepat dalam memperoleh dukungan kelompok kerja jika terjadi persaingan kerja yaitu mencapai kompetensi yang sehat dari dosen untuk melakukan perubahan. Ini juga merupakan prasyarat adanya perubahan yang efektif dalam kelompok kerja.

Kualitas pendidikan di Indonesia rendah disebabkan rendahnya mutu pembelajaran dan kelemahan kinerja guru dan dosen. Argumen dari Profesor Donald Ely dari Syracus University AS tersebut berdasarkan pada fakta calon guru yang kuliah di lembaga pendidikan tenaga kependidikan (LPTK) adalah lulusan sekolah menengah yang tidak diterima di fakultas non kependidikan. Masyarakat Indonesia yang kuliah di LPTK adalah pilihan terakhir setelah tidak diterima di mana-mana. Akibatnya, LPTK tidak bisa merekrut alumnus terbaik untuk dididik menjadi guru. Mereka inilah yang kemudian menekuni profesi guru. Mendikbud Muhammad Nuh pada saat membuka Rembuk Nasional Pendidikan di Sawangan Bogor awal 2013 mensinyalir rendahnya kualitas pendidikan disebabkan oleh kelemahan kinerja dan kompetensi profesionalisme guru dan dosen.

Salah satu kunci kesuksesan pembelajaran di Perguruan Tinggi yaitu upaya perubahan dalam diri individu dosen dipengaruhi oleh tiga hal utama, yaitu 1) 
perolehan komitmen untuk ikut serta dalam proses perubahan, dalam keadaan dimana dosen telah siap untuk berubah karena memang yang bersangkutan percaya bahwa perubahan memang perlu terjadi; 2) peningkatan kemauan merespon, agar dapat merealisasikan komitmen dosen menjadi perubahan nyata dan 3) meningkatkan keterampilan dalam berorganisasi melalui pelatihan dan memberi kesempatan untuk menyesuaikan diri dengan keterampilan yang didapat. Enam belas tahun lalu, nama Universitas Pamulang (Unpam) mungkin tidak dikenal. Namun sekarang Universitas Pamulang menjadi rumah bagi 58 ribu mahasiswa. Salah satu penyebab Unpam tidak diminati di masa lalu adalah pengelolaannya yang kurang rapi. Berdiri pada tahun 2000, manajemen Unpam berada di bawah Yayasan Primajaya. Lahan dan semua aset yang dipakai Unpam sendiri merupakan pinjaman dari Yayasan Sasmita Jaya pimpinan Darsono. Ketika itu, Darsono yang sedang fokus mengembangkan SMEA Sasmita Jaya memberi tenggat waktu kepada Yayasan Primajaya untuk mandiri dalam waktu tujuh tahun.

Namun, hingga tahun keempat, Unpam hanya menjadi almamater bagi 120 mahasiswa. Darsono, melalui Yayasan Sasmita Jaya, kemudian mengambil alih manajemen Unpam. Di era inilah masa uang kuliah murah di Unpam dimulai. Mulai dari Rp100 ribu per bulan, kini mahasiswa Unpam cukup mengeluarkan uang Rp200 ribu setiap bulannya untuk menjalani studi. Tidak ada beban uang gedung atau biaya lainnya. Kepercayaan dan animo masyarakat untuk masuk Unpam sangat tinggi. Mereka pun datang dari Sabang sampai Merauke. Saat ini, sedikitnya 58 ribu mahasiswa menempuh pendidikan tinggi di bawah asuhan 1.400 dosen Unpam.

Target Universitas Pamulang empat tahun ke depan, mempunyai 100 ribu mahasiswa yang berkuliah di Unpam untuk berbagai jurusan. Memenuhi target ini tentu tidak mudah. Salah satunya untuk memenuhi rasio dosen dan mahasiswa agar sesuai standar yang ditetapkan Kementerian Riset Teknologi dan Pendidikan Tinggi. Target Unpam adalah ingin menyekolahkan 400 calon dosen untuk memenuhi ratio tersebut.

Universitas Pamulang mengemban misi yang utama membina, mendidik, mengarahkan dan membimbing para mahasiswa sebagai harapan bangsa. Untuk itu Universitas Pamulang mengembang tugas yang berat untuk mendidik para calon dosen dan meningkatkan kinerja dosen yang sudah ada. Kepemimpinan transformasional dibutuhkan untuk memberi contoh langsung kepada dosen baru dan dosen lama untuk sama-sama membangun Universitas Pamulang yang sudah mempunyai mahasiswa hampir mencapai 100 ribu mahasiswa. Kepemimpinan transformasional dibutuhkan untuk melakukan pengembangan di bidang kurikulum yang disesuaikan dengan kebutuhan dunia kerja, sehingga seluruh lulusan Universitas Pamulang dapat diterima dengan baik dalam dunia kerja. Selain itu untuk menunjang kegiatan perkuliahan, Universitas Pamulang telah menyediakan berbagai macam fasilitas, seperti laboratorium, perpustakaan, sarana prasarana pendidikan online yaitu E-learning, organisasi pembelajaran, workshop, dan kegiatan seminar. Saat melakukan pembelajaran secara E-learning memang masih ada kendala baik untuk mahasiswa dan dosen mengingat begitu banyak mahasiswa yang ada di Unpam. Dalam mewujudkan sarana pendidikan, Universitas Pamulang melaksanakan biaya kuliah yang murah dan terjangkau oleh seluruh lapisan masyarakat tanpa melupakan kualitas dari pendidikan itu sendiri. Oleh karena itu Universitas Pamulang selalu mengangkat tenaga pengajar dan staff administrasi yang berkompeten di bidangnya. 


\section{B. Pembatasan Masalah}

Dari berbagai permasalahan yang telah diidentifikasikan tersebut, terdapat banyak masalah. Namun tidak semua permasalahan itu akan dibahas karena keterbatasan waktu dan ruang lingkup bahasan, maka penelitian ini dibatasi pada beberapa variabel yaitu pengaruh kepemimpinan transformasional, organisasi pembelajaran, dan komitmen organisasi, terhadap kinerja dosen.

\section{Perumusan Masalah}

Berdasarkan latar belakang masalah, identifikasi masalah, dan pembatasan masalah yang telah dijelaskan di atas maka dalam penelitian ini dapat dirumuskan permasalahan sebagai berikut :

1. Apakah kepemimpinan transformasional berpengaruh langsung terhadap kinerja?

2. Apakah organisasi pembelajaran berpengaruh langsung terhadap kinerja?

3. Apakah komitmen organisasi berpengaruh langsung terhadap kinerja?

4. Apakah kepemimpinan transformasional berpengaruh langsung terhadap komitmen organisasi ?

5. Apakah organisasi pembelajaran berpengaruh langsung terhadap komitmen organisasi?

\section{TEORI DAN KERANGKA PEMIKIRAN}

\section{A. Kepemimpinan Transformasional dan Kinerja}

Kepemimpinan transformasional adalah model perilaku kepemimpinan yang menggabungkan dan menyempurnakan konsep-konsep terdahulu yaitu pemimpin transformasional sebagai pemimpin penerobos (breakthrough leadership). Disebut sebagai pemimpin penerobos karena pemimpin dengan karakter ini mempunyai kemampuan untuk membawa perubahan-perubahan yang sangat besar terhadap individu-individu maupun organisasi. Caranya adalah dengan jalan: memperbaiki kembali karakter diri individu dalam organisasi ataupun perbaikan organisasi, memulai proses penciptaan inovasi, meninjau kembali struktur, proses dan nilai-nilai organisasi agar lebih baik dan lebih relevan. Dilakukan dengan cara menarik dan menantang bagi semua pihak yang terlibat dan mencoba untuk merealisasikan tujuan-tujuan organisasi yang selama ini dianggap tidak mungkin dilaksanakan, menyatakan bahwa tipe kepemimpinan ini tidak hanya sekedar menggunakan kekuatan dan kekuasaan dalam mencapai tujuan, namun juga mampu mempengaruhi anggota organisasi dengan cara yang sesuai.

Cara yang sesuai menyebabkan pegawai senang dalam menerima tugas dari pemimpin sehingga pegawai puas dalam bekerja dan tidak menganggap tugas tersebut sebagai beban dalam bekerja. Pemimpin transformasional memiliki karakter sebagai berikut:

1. pemimpin mengidentifikasi dirinya sebagai alat perubahan

2. pemimpin berani

3. pemimpin mempercayai orang lain

4. pemimpin motor penggerak nilai

5. pemimpin pembelajar sepanjang masa 
6. pemimpin memiliki kemampuan menghadapi kompleksitas, ambiguitas, dan ketidakpastian

7. pemimpin visioner.

Kepemimpinan transformasional akan memberikan pengaruh langsung positif pada hubungan antara atasan dan bawahan. Pimpinan transformasional selalu membimbing kinerja pegawai secara individul maupun secara tim kerja sehingga dapat dikatakan kepemimpinan transformasional berpengaruh langsung positif terhadap kinerja.

Dengan kepemimpinan transformasional para pengikut merasakan kepercayaan, kekaguman, kesetiaan dan penghormatan terhadap pemimpin dan mereka termotivasi untuk melakukan lebih daripadayang awalnya diharapkan dari mereka. Menurut Bass, pemimpin mengubah dan memotivasi para pengikut dengan:

1. Membuat mereka lebih menyadari pentingnya hasil tugas

2. Membujuk mereka untuk mementingkan kepentingan tim atau organisasi mereka dibandingkan dengan kepentingan pribadi.

3. Mengaktifkan kebutuhan mereka yang lebih tinggi.

Kepemimpinan transformasional lebih meningkatkan motivasi dan kinerja pengikutnya dalam hal ini di perguruan tinggi pemimpin adalah Dekan, rektor sedangkan pengikutnya adalah Dosen.

Dengan perubahan-perubahan positif tersebut, kepemimpinan transformasional yang dipakai di perguruan tinggi siap mentransfer kekuatan para dosen untuk bekerja dan berkompetensi dalam melaksanakan tugas mengajar dan siap untuk menerima tugas yang diberikan pemimpin tanpa beban, senang dan puas dalam melakukan pekerjaannya serta meningkatkan produktivitas dan kinerja dosen yang bersangkutan.

Dari penjabaran tersebut maka kepemimpinan transformasional mempunyai pengaruh langsung positif terhadap kinerja.

\section{B. Organisasi Pembelajaran dan Kinerja}

Organisasi yang sukses dalam mendapatkan, menanamkan dan menerapkan pengetahuan yang dapat dipergunakan untuk membantu menerima perubahan para anggotanya dinamakan organisasi pembelajaran, yakni sebuah organisasi yang membangun kapasitas, menyesuaikan untuk berubah secara terus-menerus.

Teori dari Colquitt, LePine, Wesson menyatakan bahwa:

"person organization fit has a weak positive effect on performance. Employees who fit with teir organization tend to have slightly higher levels of task performance, with effects on citizenship behaviour slightly stronger.

Person organization fit $\rightarrow$ Job performance

Dari teori Colquitt menyatakan bahwa organisasi pembelajaran mempunyai pengaruh yang positif terhadap kinerja. Organisasi pembelajaran erat hubungannya dengan organisasi atau perusahaan yang menyediakan tempat untuk anggotanya. Dalam hal ini pegawai untuk belajar terus menerus agar lebih berkembang dan meningkatkan diri dalam memperdalam ilmu pengetahuan dan teknologi yang dapat digunakan saat bekerja. Organisasi pembelajaran memudahkan anggota organisasi untuk selalu meningkatkan pengetahuan dengan cara sharing dengan sesama anggota. 
Setiap karyawan melakukan kinerja diantaranya adalah kinerja dosen yang bekerja pada institusi pendidikan atau perguruan tinggi. Sebagai karyawan, dosen sangat tergantung dengan organisasi pembelajaran yang ada di dalam perguruan tinggi tersebut. Menurut Podsakof, manajemen perubahan adalah proses secara sistematis dalam menerapkan pengetahuan, sarana, sumber daya yang diperlukan untuk mempengaruhi perubahan pada orang yang akan terkena dampak dari proses tersebut.

Menurut Podsakof juga pendekatan dalam manajemen perubahan adalah: a) mengidentifikasi siapa, di antara mereka yang terkena dampak perubahan, yang mungkin menolak perubahan, b) menelusuri sumber, tipe dan tingkat resistensi perubahan yang mungkin ditemukan, dan c) mendesain strategi yang efektif untuk mengurangi resistensi tersebut. Proses perubahan terdiri dari tiga elemen yang saling berhubungan, yaitu: (1) objectives and outcomes, (2) planning the change dan (3) people. Untuk mengelola pembelajaran, ada beberapa hal yang dapat dilakukan pimpinan, diantaranya adalah langkah-langkah: (a) menciptakan strategi, dilakukan dengan bersedianya membuat komitmen secara eksplisit terhadap perubahan, melakukan inovasi dan perbaikan terus-menerus. (b) merancang ulang struktur organisasi, dilakukan dengan meratakan struktur, membatasi atau mengkombinasikan antar bagian, dan meningkatkan penggunaan tim lintas antar fungsi, saling ketergantungan diperkuat dan batas-batas diantara orang dapat dikurangi. 3) membentuk kembali budaya organisasi, sehingga sebagai organisasi pembelajaran mempunyai karakteristik dan memperlihatkan keterbukaan dan pertumbuhan.

Organisasi pendidikan dalam hal ini perguruan tinggi dapat sukses dalam mendapatkan, menanamkan dan menerapkan pengetahuan yang dapat dipergunakan untuk membantu menerima perubahan dinamakan organisasi pembelajaran. Sebuah organisasi yang membangun kapasitas menyesuaikan dan berubah secara terusmenerus. Jika organisasi perguruan tinggi dalam melakukan perubahan pembelajaran terhadap para dosen dan apabila mereka melakukan kesalahan. Dosen dapat menempuh cara menganalisa hasil kinerja saat melakukan proses pembelajaran dan memperbaikinya, hal ini sangat berpengaruh terhadap dosen melakukan kinerja dalam mendidik mahasiswa untuk menjadikan lulusan dengan mutu terbaik. Kinerja yang baik akan membuat persaingan yang sehat diantara sesama dosen dengan tujuan mengejar karir yang baik.

Teori yang mendukung dari organisasi pembelajaran terhadap kinerja dari Marshall Goldsmith, Howard and Alexander J.Ogg bahwa:

"learning organizations identified four learning styles that represent ways in which organizations generate ideas with possitive impact: experimentation, competency acquisition, bench-marking, and continuous improvement.

Dalam organisasi pembelajaran dikelompokkan menjadi empat model pembelajaran yang mewakili dan menunjukan ada pengaruh yang positif dalam kinerja yaitu melakukan percobaan, kemahiran dan kompetensi standar yang digunakan dan kelanjutan kemajuannya.

Kunci kesuksesan dosen dalam meningkatkan kinerja adalah upaya perubahan dalam mengejar karir individu dipengaruhi oleh tiga hal utama, yaitu (a) perolehan komitmen dosen untuk melakukan persaingan dan ikut serta dalam proses perubahan, dalam keadaan dimana individu telah siap untuk berubah karena memang yang 
bersangkutan percaya bahwa perubahan memang perlu terjadi; (b) peningkatan kemauan dosen dalam merespon, agar dapat merealisasikan komitmen individu menjadi perubahan nyata dalam berkarir sebagai pendidik dan (c) mengikuti pembentukan keterampilan-keterampilan baru melalui pelatihan dan pemberian waktu untuk menyesuaikan diri dengan keterampilan baru tersebut.

Colquitt juga menyatakan dalam teorinya bahwa:

"learning has a moderate positive effect on performance. Employees who gain more knowledge and skill tend to have higher levels of task performance." Learning $\rightarrow$ Job performance

Pembelajaran mempunyai pengaruh positif dalam kinerja pegawai. Para pegawai yang memperoleh pengetahuan dan kemampuan lebih banyak cenderung mempunyai tugas dan tingkat yang lebih tinggi dalam menjalankan tugasnya. Jika pembelajaran dilakukan dalam perusahaan maka dinamakan organisasi pembelajaran mempunyai pengaruh langsung positif terhadap kinerja,

Organisasi pembelajaran dalam perguruan tinggi yang diikuti dengan baik oleh dosen akan menghasilkan kualitas dalam kinerja mendidik dan mempunyai keterampilan yang tergali dari potensi diri dosen melalui kelompok kerja para pendidik melalui pendidikan latihan dan menimbulkan hasil unjuk kerja yang tinggi dan memuaskan diantara para dosen.

Penjelasan di atas dapat diambil benang merahnya yaitu learning organisasi berpengaruh langsung positif terhadap kinerja.

\section{Komitmen Organisasi dan Kinerja}

Teori tentang commitment organizational and job performance dari Ivanka Menken menyatakan bahwa:

"commitment organization is the systematic application of behavioral science knowledge at various levels, such as group, inter-group, organization etc. to bring about planned change. The commitment organizations objective is a higher quality of work life, productivity, adaptability, and effectiveness. It accomplishes this by changing attitudes, behaviors, values, strategies, procedures, and structures, so commitment organizations possitive impact to job performance, technological advances, and the fast pace of change within the environment."

Komitmen organisasi adalah sebuah penerapan sistem dalam ilmu pengetahuan terhadap tingkatan yang bermacam-macam seperti kelompok, hubungan antar kelompok, organisasi dan sebagainya, dalam perubahan perencanaan. Tujuan komitmen organisasi adalah kualitas yang lebih tinggi terhadap lingkungan pekerjaan, produktivitas, kemampuan adaptasi dan keefektifan. Keberhasilan itu dilakukan dengan merubah sikap, prilaku, nilai-nilai, strategi-strategi, prosedur, dan sesuatu yang direncanakan, sehingga terdapat pengaruh langsung positif komitmen organisasi terhadap kinerja. Dari teori tersebut dinyatakan komitmen organisasi berpengaruh langsung positif terhadap kinerja.

Dosen adalah tenaga pendidik yang memberikan sejumlah ilmu pengetahuan kepada anak didik di kampus. Dosen adalah orang yang berpengalaman dalam bidang profesinya. Dengan keilmuan yang dimilikinya dia dapat menjadikan anak didik menjadi orang yang cerdas. 
Dosen adalah salah satu komponen manusiawi dalam proses belajar, yang ikut berperan dalam usaha pembentukan sumber daya manusia yang potensial di bidang pembangunan. Kemampuan mengelola proses belajar mengajar menjadi kesanggupan atau kecakapan para dosen dalam menciptakan suasana komunikasi yang edukatif antara dosen dan peserta didik yang mencakup segi kognitif, afektif dan psikomotor, sebagai upaya mempelajari sesuatu berdasarkan perencanaan sampai dengan tahap evaluasi dan tindak lanjut agar tercapai tujuan pengajaran.

Dosen akan merasakan adanya rasa adil di tempat ia mengajar apabila mereka bisa diberdayakan oleh lembaga pendidikan. Pemberdayaan dosen ialah suatu kegiatan atau proses yang ditujukan untuk memelihara dan meningkatkan kemampuan, sikap, pengertian dan kinerja dosen dalam peranannya sebagai tenaga akademik pada masa kini dan masa yang akan datang. Pemberdayaan dosen diperlukan untuk meningkatkan mutu kinerja jurusan dalam menghadapi berbagai tantangan yang selalu berubah dari waktu ke waktu dalam pelaksanaan misi jurusan. Pemberdayaan dosen yang berhasil akan meningkatkan kompetensi pedagogik yang dapat meningkatkan mutu lulusan dalam bidang ilmu pengetahuan, teknologi dan seni. Pemberdayaan dosen dimaksudkan untuk mengakomodasi hasrat dosen untuk mengembangkan diri dan meningkatkan karirnya. Kepentingan pribadi dosen diharapkan juga diperhatikan dalam perencanaan dan pelaksanaan pemberdayaannya.

Komitmen organisasi yang dimiliki oleh dosen juga berpengaruh pada kinerja atau rasa keterikatan mereka pada lembaga pendidikan tempat ia mengajar. Kinerja juga berhubungan dengan karakteristik yang mendasari seseorang dan berkaitan dengan efektifitas kinerja individu dalam pekerjaannnya. Kinerja mencakup berbagai faktor teknis dan non teknis, kepribadian dan tingkah laku. Kemudian banyak dipergunakan sebagai aspek yang dinilai banyak organisasi termasuk organisasi pendidikan untuk merekrut staf pengajar ke dalam lembaga pendidikan. Dosen yang memiliki persepsi bahwa kinerja mereka benar-benar dimanfaatkan oleh lembaga pendidikan tempat ia mengajar yang ditandai dengan adanya pemberdayaan di tempat kerja, akan cenderung menemukan rasa nyaman dalam bekerja. Terlepas dari berbagai kelebihan dan kekurangan dosen, yang harus dilakukan adalah menyiapkan sosok dosen masa depan yang profesional sesuai tuntutan reformasi pendidikan yang sekarang ini sedang bergulir. Untuk itu diperlukan sebuah regulasi dan program pengembangan profesionalisme dosen yang komprehensif yang melibatkan berbagai pihak, mulai dari perguruan tinggi, pemerintah, masyarakat, serta stakeholder yang lain agar kinerja dosen dapat meningkat sesuai dengan kemajuan jaman

Kinerja merupakan seperangkat pengetahuan, keterampilan, dan perilaku yang harus dimiliki, dihayati, dan dikuasai oleh dosen dalam melaksanakan tugas keprofesionalan mencerdaskan dan mentransfer ilmu ke mahasiswa sehingga menghasilkan wisudawan yang handal dan berkualitas saat terjun kerja di masyarakat.

\section{Kepemimpinan Transformasional dan Komitmen Organisasi}

Hubungan kepemimpinan transformasional dan komitmen organisasi berpengaruh sangat besar mengingat komitmen organisasi dapat berjalan dengan baik apabila kepemimpinan transformasional dapat dilakukan dan diterapkan pimpinan kepada para pegawai di lingkungan nya. 
Teori dari Colquitt, LePine dan Watson menyatakan bahwa: "tranformational leadership has a strong possitive effect on commitment. Employees with tranformational leaders tend to have higher levels of affective commitment and higher levels of normative commitment."

Teori Colquitt menyatakan Kepemimpinan transformasional mempunyai pengaruh positif yang kuat terhadap komitmen organisasi. Kepemimpinan transformasional adalah pemimpin yang memotivasi bawahan untuk melakukan kerja dan mencapai hasil tertentu melebihi dari apa yang semula diharapkan. Hasil temuan tersebut dapat dipahami bahwa sebenarmya pengaruh kepemimpinan terhadap komitmen organisasi menunjukkan pembuktian yang sama, tetapi pegawai mempunyai kekuatan yang lebih besar yaitu pegawai mempunyai komitmen yang tinggi dalam berorganisasi.

Dosen adalah salah satu komponen penting dalam suatu sistem pendidikan di perguruan tinggi. Peran, tugas, dan tanggung jawab dosen sangat penting dalam mewujudkan tujuan pendidikan nasional, yaitu mencerdaskan kehidupan bangsa, meningkatkan kualitas manusia Indonesia, meliputi kualitas iman dan takwa, akhlak mulia, dan penguasaan ilmu pengetahuan, teknologi, dan seni, untuk mewujudkan masyarakat Indonesia yang maju, adil, makmur, dan beradab. Untuk melaksanakan fungsi, peran, dan kedudukan yang sangat strategis tersebut, perguruan tinggi memerlukan dosen yang profesional. Dosen dianggap sebagai komponen terpenting pendidikan tinggi, yang dianggap sebagai jalan yang tepat membantu para kaum muda untuk dapat menjadi insan yang sempurna, yang memiliki ciri cerdas dan kompetitif.

Keberhasilan perguruan tinggi dalam meningkatkan mutu lulusan dapat dicapai oleh pimpinan fakultas yang memiliki keterampilan memimpin yang sudah teruji, didukung oleh fasilitas yang memadai. Colquitt menyatakan bahwa kepemimpinan transformasional dapat mempengaruhi pegawai dalam melakukan kinerja dan berkarya sekaligus mempengaruhi dalam komitmen organisasi.

Kepemimpinan fakultas memiliki pengaruh dalam membentuk sikap dan perilaku dosen di kampus. Dosen adalah salah satu komponen esensial dalam suatu sistem pendidikan di perguruan tinggi. Peran, tugas, dan tanggungjawab dosen sangat penting dalam mewujudkan tujuan pendidikan nasional, yaitu mencerdaskan kehidupan bangsa, meningkatkan kualitas manusia Indonesia, meliputi kualitas iman dan takwa, akhlak mulia, dan penguasaan ilmu pengetahuan, teknologi, dan seni, untuk mewujudkan masyarakat Indonesia yang maju, adil, makmur, dan beradab. Untuk melaksanakan fungsi, peran, dan kedudukan yang sangat strategis tersebut, perguruan tinggi memerlukan dosen yang profesional. Dosen dianggap sebagai komponen terpenting pendidikan tinggi, yang dianggap sebagai jalan yang tepat membantu para kaum muda untuk dapat menjadi insan yang sempurna, yang memiliki ciri cerdas dan kompetitif.

Kepemimpinan akan efektif apabila didukung berbagai perilaku yang baik termasuk berorientasi pada hasil, mampu mengelola kinerja, berprakarsa, perhatian pada komunikasi, memberdayakan dan mengembangkan bawahan, membangun komitmen organisasi, dan menetapkan fokus.

Dari penjelasan di atas dapat dikatakan bahwa kepemimpinan transformasional berpengaruh langsung positif terhadap komitmen organisasi. 


\section{E. Organisasi Pembelajaran dan Komitmen Organisasi}

Dalam mempersiapkan diri melalui pengembangan sumber daya manusia dengan orientasi organisasi. Masa depan melalui organisasi pembelajaran yaitu organisasi tempat para anggotanya untuk senantiasa belajar secara bersama-sama dan berkesinambungan guna memperluas kapasitas. Hal ini untuk menciptakan masa depan yang baru atau yang diinginkan melalui pola berpikir sistemik dan memecahkan masalah bersama.

Ini adalah salah satu cara bagi perguruan tinggi untuk meningkatkan kemampuan kinerja dosen. Dosen sebagai pegawai yang bekerja di perguruan tinggi merupakan sumber daya manusia yang berkualitas untuk menghasilkan para lulusan dari mahasiswa yang di didik untuk dapat terjun ke masyarakat.

Membudayakan proses belajar (learning process) yaitu suatu proses individu atau sekelompok individu memperoleh dan menguasai pengetahuan baru yang membawa dampak pada perubahan perilaku dan tindakan serta perkembangan kemampuan mereka di dalam organisasi dan menjadikan organisasi sebagai organisasi pembelajaran.

Perguruan tinggi baik negeri maupun swasta dapat menerapkan organisasi pembelajaran diawali oleh adanya pengakuan bahwa kekuatan organisasi tergantung kepada kemampuan para dosen untuk aktif dalam organisasi pembelajaran. Organisasi pembelajaran mendukung paradigma bahwa sumber daya manusia sebagai aset utama organisasi untuk mencapai kinerja, daya saing dan kesuksesan organisasi. Organisasi pembelajaran memfasilitasi pembelajaran dan pengembangan kapasitas sumber daya manusia dalam organisasi secara konstan dan menjamin semua sumber daya manusia mendapatkan peluang dan akses belajar guna meningkatkan kapasitasnya. Organisasi pembelajaran memiliki kemampuan untuk mengubah persepsi, perilaku, nilai, model mental, strategi dan kebijakan orang-orang dan organisasi melalui pembelajaran individu dan kelompok yang terhubung dengan organisasi pembelajaran dengan cara-cara yang jelas dan terstruktur. Mengajari individu untuk berpikir kritis dan bagaimana individu dalam organisasi membantu organisasi mencapai pembelajaran tampaknya menjadi kata kunci yang dapat mengantarkan organisasi untuk berubah lebih cepat dan lebih pintar dari lingkungannya.

Pelatihan berupa diklat yang diberikan untuk dosen yang harus diikuti berguna untuk lebih meningkatkan kinerjanya.

Teori dari Colquitt, Wesson dan Le Pine menyatakan tentang hubungan antara learning organisasi dengan komitmen organisasi bahwa:

"learning organization has a positive effect on commitment. Employees who gain more knowledge and skill tend to have slightly higher levels of affective commitment."

Organisasi pembelajaran mempunyai pengaruh positif terhadap komitmen pegawai. Para pegawai yang mempunyai pengetahuan dan kemampuan yang lebih banyak dan mempunyai pandangan tingkatan yang lebih tinggi terhadap komitmen yang efektif.

Organisasi pembelajaran menurut Colquitt merupakan suatu kondisi atau iklim yang dapat mendorong dan mempercepat, individu, kelompok dan organisasi untuk 
belajar dan pada akhirnya mempunyai pengaruh yang positif untuk komitmen dalam organisasi.

Menurut Colquitt bahwa: "person organization fit has a strong positive effect on commitment. Employees who fit with their organization tend to have higher levels of affective commitment." Organisasi perseorangan berpengaruh positif sangat kuat terhadap komitmen. Para pegawai yang cocok dengan organisasi mereka dengan tingkatan yang lebih tinggi terhadap komitmen yang efektif. Proses berpikir kritis dalam memahami sesuatu yang seharusnya dilaksanakan dan untuk apa melaksanakannya. Organisasi pembelajaran yang disediakan sebagai tempat untuk mengembangkan cara berpikir anggotanya menjadi lebih cerdas dan kritis dalam berfikir dan bertindak. $\mathrm{Hal}$ ini menyebabkan para pegawai mempunyai keterikatan yang kuat dengan organisasi kerjanya sehingga ada kemauan dan komitmen dari anggota untuk tetap menjadi anggota organisasi tersebut.

Dosen adalah sumber daya manusia dalam organisasi di perguruan tinggi, yang berperan penting dalam membantu organisasinya untuk belajar dari kesalahan, kegagalan dan keberhasilan. Dengan mengubah kinerja yang salah di periode sebelumnya maka dosen dapat meningkatkan kinerjanya. Ingin selalu berkembang dan belajar terus menerus melalui organisasi pembelajaran.

Dengan demikian pegawai sadar dan mengakui berbagai perubahan lingkungan dan berusaha beradaptasi dengan cara yang lebih efektif, sehingga dapat mengetahui keberadaan organisasi dari kemampuannya. Kemampuan individu dalam organisasi adalah kumpulan yang terstruktur untuk mencapai tujuan yang telah disepakati bersama.

Sebagai pendidik profesional, dosen di masa yang akan datang tidak hanya tampil lagi sebagai pengajar, seperti fungsinya yang menonjol selama ini, melainkan beralih menjadi motivator, inspirator, pelatih, inovator dalam pembelajaran, pembimbing, konselor, dan manager belajar. Kunci keberhasilan dari komitmen organisasi dosen adalah semakin aktif mengasah diri di organisasi pembelajaran perguruan tinggi tersebut maka kemampuan kompetensi mengajar dosen semakin baik dan tergali secara maksimal.

Dari teori tersebut mekanisme perseorangan mempunyai pengaruh langsung terhadap pekerjaan dan komitmen organisasi, dan mekanisme perseorangan adalah stress, kepuasan, motivasi, kepercayaan, dan pembelajaran.

\section{METODOLOGI PENELITIAN}

Penelitian ini dilakukan dengan menggunakan metode survei dengan menggunakan analisis jalur (path analysis). Cara untuk mengumpulkan data yang diperlukan dalam penelitian ini dilakukan melalui kuesioner dan tes yang telah disusun terlebih dahulu. Penelitian ini akan mengkaji keterkaitan antar variabel penelitian, serta mengukur pengaruh variabel yang satu dengan variabel lainnya. Dalam penelitian ini terdapat empat variabel yang akan dikaji, yaitu kepemimpinan transformasional, organisasi pembelajaran, komitmen organisasi dan kinerja. Populasi merupakan keseluruhan dari kumpulan elemen yang memiliki sejumlah karakteristik umum, yang terdiri dari bidang-bidang untuk di teliti atau, keseluruhan kelompok dari orang-orang, peristiwa atau barang-barang yang diminati oleh peneliti untuk diteliti. Populasi 
penelitian adalah para dosen yang bekerja di perguruan tinggi Universitas Pamulang di daerah Tangerang Selatan. Jumlah dosen di Universitas Pamulang adalah 150 orang.

Adapun sampel yang digunakan dalam penelitian ini adalah dari dosen. Teknik pengambilan sampel yang digunakan dalam penelitian ini adalah dengan melalui purposive sampling. Dalam purposive sampling, masing-masing elemen populasi mempunyai kemungkinan pemilihan yang sama. Selanjutnya setiap kemungkinan sampel dari ukuran tertentu ini mempunyai kemungkinan yang sama untuk dipilih.

Teknik pengambilan sampel adalah suatu cara dipergunakan untuk menentukan ukuran sampel penelitian. Besarnya sampel tidak boleh kurang dari $95 \%$ dari populasi yang ada. Untuk memenuhi kriteria tersebut maka pengukuran sampel dihitung dengan menggunakan rumus Slovin sebagai berikut:

$$
n=\frac{N}{1+N e^{2}}
$$

Keterangan

$\mathrm{n}=$ jumlah sampel

$\mathrm{N}=$ jumlah populasi

$\mathrm{e}=$ presisi yang digunakan

Jumlah populasi dalam penelitian ini adalah sebanyak 150 orang. Presisi yang diambil sekitar 95 hingga 90\%. Namun dalam penelitian ini diambil presisi pengambilan sampel $95 \%$ untuk menjaga representatif dari sampel penelitian. Sehingga diperoleh:

$$
\begin{aligned}
& n=\frac{150}{1+150 \cdot(0,05)^{2}} \\
& n=109,09 \text { orang }
\end{aligned}
$$

Sehingga sampel penelitian ini adalah 109 orang.

Syarat analisis jalur (path analysis) adalah estimasi antara variabel eksogen terhadap variabel endogen bersifat linear, dengan demikian persyaratan yang berlaku pada analisis regresi dengan sendirinya juga berlaku pada persyaratan analisis jalur.

Nilai koefisien jalur pada sub struktur model adalah jalur yang menghubungkan instrumen kepemimpinan transformasional terhadap instrumen komitmen organisasi, dan jalur yang menghubungkan instrumen learning organisasi terhadap instrumen komitmen organisasi. Ringkasan model dapat terlihat pada gambar berikut:

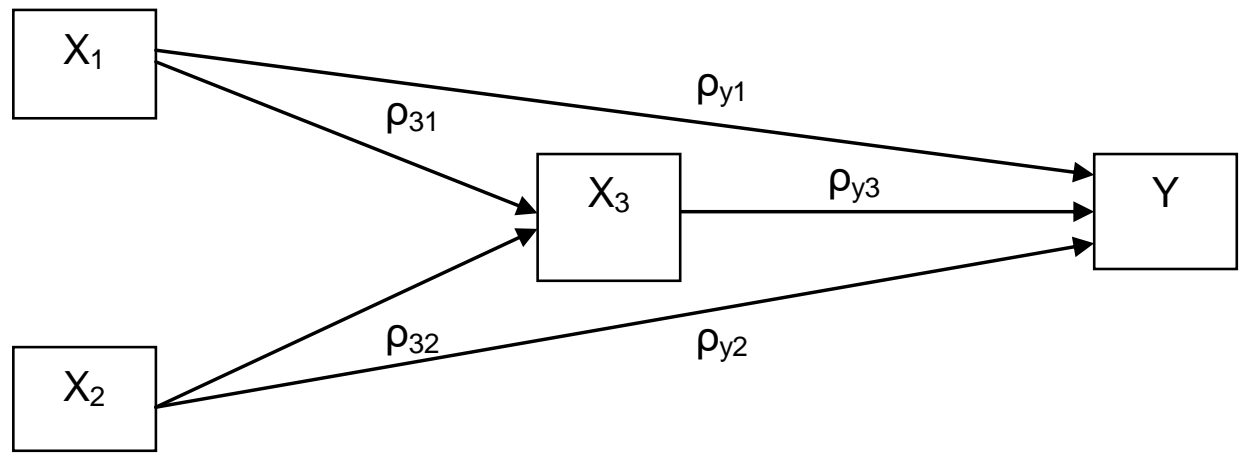

Gambar 1. : Model Hubungan Struktural Antar Variabel 


\section{HASIL DAN PEMBAHASAN}

A. Hasil penelitian

Dari hasil analisis dan proses perhitungan yang dilakukan pada bagian pengaruh langsung, dapat dirangkum sebagai berikut:

Hasil pengujian koefisien korelasi dapat dirangkum seperti pada tabel 2 berikut ini :

Tabel 2. : Rangkuman Hasil Pengujian Koefisien Korelasi

\begin{tabular}{|l|l|l|c|}
\hline \multirow{2}{*}{ Matrik } & \multicolumn{3}{|c|}{ Koefisien Korelasi } \\
\cline { 2 - 4 } & \multicolumn{1}{|c|}{$\mathbf{X}_{\mathbf{2}}$} & \multicolumn{1}{c|}{$\mathbf{X}_{\mathbf{3}}$} & $\mathbf{Y}$ \\
\hline $\mathbf{X}_{\mathbf{1}}$ & - & $\mathrm{r}_{13}=0,281$ & $\mathrm{r}_{1 \mathrm{y}}=0,383$ \\
\hline $\mathbf{X}_{\mathbf{2}}$ & & $\mathrm{r}_{23}=0,286$ & $\mathrm{r}_{2 \mathrm{y}}=0,394$ \\
\hline $\mathbf{X}_{\mathbf{3}}$ & & & $\mathrm{r}_{3 \mathrm{y}}=0,417$ \\
\hline
\end{tabular}

Setelah mendapatkan besaran koefisien korelasi dan koefisien jalur, bentuk model struktural dapat terlihat pada gambar 2. sebagai berikut :

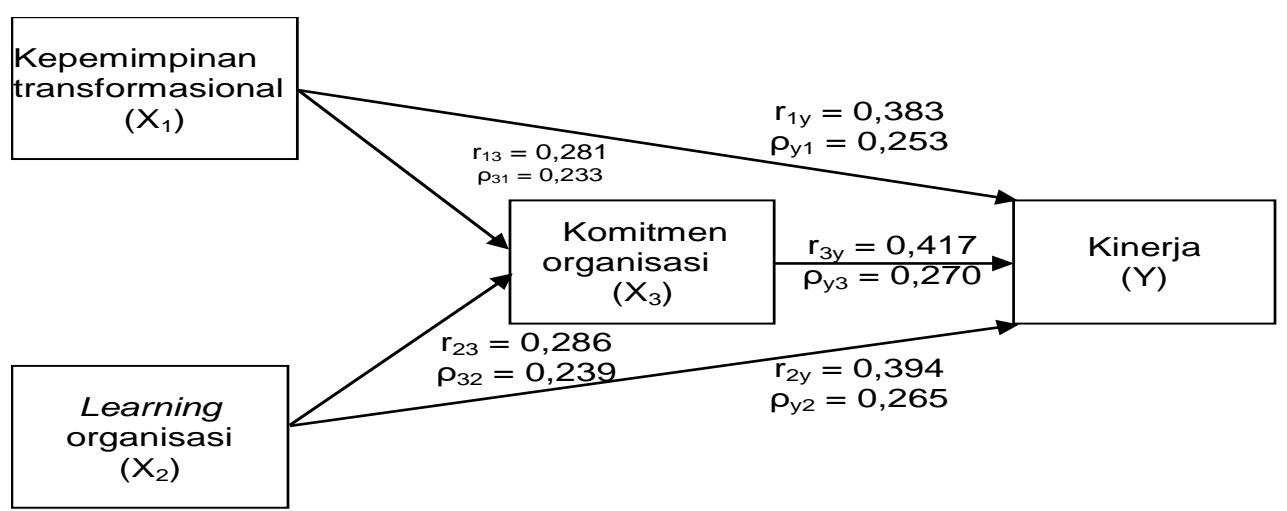

Gambar 2 : Model Hubungan Struktural antar Variabel

Persamaan struktural yang terbentuk pada model sub struktur kedua yang dibentuk oleh koefisien jalur dari variabel $X 1$ ke $X_{3}$ dan $X 2$ ke $X_{3}$ berupa: $X_{3}=\beta_{31} X_{1}+$ $\beta_{32} X_{2} \quad \beta_{3} \varepsilon_{2}$. Dengan besar $\left(R_{3.12}\right)^{2}=0,1336$ sehingga $\beta_{3} \varepsilon_{2}=0,931$. Jadi bentuk persamaan struktural pada model sub struktur kedua:

$X_{3}=0,233 X_{1}+0,239 X_{2}+0,931$.

Adapun hasil analisis pengaruh langsung antar variabel seperti pada table $3 \mathrm{di}$ bawah ini :

Tabel 3. : Pengaruh Langsung Antar Variabel

\begin{tabular}{|c|c|c|c|c|c|c|}
\hline \multirow{2}{*}{ No. } & \multirow{2}{*}{$\begin{array}{l}\text { Pengaruh } \\
\text { Langsung }\end{array}$} & \multirow{2}{*}{$\begin{array}{c}\text { Koefisien } \\
\text { Jalur }\end{array}$} & \multirow{2}{*}{ dk } & \multirow{2}{*}{$t_{\text {hitung }}$} & \multicolumn{2}{|c|}{$t_{\text {tabel }}$} \\
\hline & & & & & $\alpha=0,05$ & $\alpha=0,01$ \\
\hline 1. & $\mathrm{X}_{1}$ terhadap $\mathrm{Y}$ & 0,253 & 105 & 2,99 ** & 1,98 & 2,62 \\
\hline 2. & $\mathrm{X}_{2}$ terhadap $\mathrm{Y}$ & 0,265 & 105 & $3,13^{* *}$ & 1,98 & 2,62 \\
\hline 3. & $\mathrm{X}_{3}$ terhadap $\mathrm{Y}$ & 0,270 & 105 & $3,12^{* *}$ & 1,98 & 2,62 \\
\hline 4. & $\mathrm{X}_{1}$ terhadap $\mathrm{X}_{3}$ & 0,233 & 106 & 2,52 * & 1,98 & 2,62 \\
\hline 5. & $\mathrm{X}_{2}$ terhadap $\mathrm{X}_{3}$ & 0,239 & 106 & 2,59 * & 1,98 & 2,62 \\
\hline
\end{tabular}

* = signifikan ( $t_{\text {hitung }}>t_{\text {tabel }}$ pada $\alpha=0,05$ )

** $=$ sangat signifikan $\left(t_{\text {hitung }}>t_{\text {tabel }}\right.$ pada $\alpha=0,01$ 


\section{B. Pembahasan}

Hasil yang diperoleh setelah melakukan analisis model digunakan sebagai dasar dalam menjawab hipotesis dan menarik kesimpulan pada penelitian ini. Penjelasan terhadap jawaban hipotesis tersebut dapat diuraikan sebagai berikut:

Dari hasil perhitungan analisis jalur, pengaruh langsung kepemimpinan transformasional $(\mathrm{X} 1)$ terhadap kinerja $(\mathrm{Y})$, dengan nilai koefisien korelasi sebesar 0,383 dan nilai koefisien jalur sebesar 0,253. Ini memberikan makna kepemimpinan transformasional (X1) berpengaruh secara langsung terhadap kinerja (Y) dapat diterima.

Dari hasil perhitungan analisis jalur, pengaruh langsung organisasi pembelajaran $(X 2)$ terhadap kinerja $(Y)$, dengan nilai koefisien korelasi sebesar 0,394 dan nilai koefisien jalur sebesar 0,265. Ini memberikan makna organisasi pembelajaran (X2) berpengaruh secara langsung terhadap kinerja $(\mathrm{Y})$ dapat diterima.

Nilai ini memberikan pengertian bahwa learning organisasi yang dilakukan di Universitas Pamulang berpengaruh secara langsung terhadap kinerja para dosen terbukti dari penelitian dan dibuktikan dengan uji statistik yang sudah dilakukan nilai koefisien korelasi sebesar 0,394 dan nilai koefisien jalur sebesar 0,265. Learning organisasi bagi dosen merupakan tempat untuk saling sharing, bertukar pengetahuan jika ada hambatan dalam bekerja, maka efektifitas dari learning organisasi akan memberikan pengaruh langsung positif secara efektif dalam kinerja.

Dari hasil perhitungan analisis jalur, pengaruh langsung komitmen organisasi (X3) terhadap kinerja (Y), dengan nilai koefisien korelasi sebesar 0,417 dan nilai koefisien jalur sebesar 0,270. Ini memberikan makna komitmen organisasi (X3) berpengaruh secara langsung positif terhadap kinerja $(\mathrm{Y})$ dapat diterima. Hasil analisis hipotesis ketiga menghasilkan temuan bahwa komitmen organisasi berpengaruh langsung positif terhadap kinerja. Berdasarkan hasil temuan tersebut dapat dikatakan komitmen organisasi di Universitas Pamulang menghasilkan nilai koefisien korelasi sebesar 0,417 dan nilai koefisien jalur sebesar 0,270 . Nilai ini memberikan pengertian bahwa komitmen organisasi dosen di Universitas Pamulang meningkatkan kinerja dosen. Meningkatnya komitmen organisasi akan berpengaruh secara langsung terhadap peningkatan kinerja.

Dari hasil perhitungan analisis jalur, pengaruh langsung kepemimpinan transformasional (X1) terhadap komitmen organisasi (X3), dengan nilai koefisien korelasi sebesar 0,281 dan nilai koefisien jalur sebesar 0,233. Ini memberikan makna kepemimpinan transformasional (X1) berpengaruh secara langsung terhadap komitmen organisasi (X3) dapat diterima.

Kepemimpinan transformasional sangat berpengaruh terhadap kinerja dosen di Universitas Pamulang setelah dilakukan penelitian dan diuji secara statistik dengan nilai koefisien korelasi sebesar 0,281 dan nilai koefisien jalur sebesar 0,233. Berdasarkan temuan tersebut dapat disimpulkan bahwa komitmen organisasi dipengaruhi secara langsung positif oleh kepemimpinan transformasional.

Dari hasil perhitungan analisis jalur, pengaruh langsung organisasi pembelajaran (X2) terhadap komitmen organisasi (X3), dengan nilai koefisien korelasi sebesar 0,286 dan nilai koefisien jalur sebesar 0,239. Ini memberikan makna 
organisasi pembelajaran (X1) berpengaruh secara langsung terhadap komitmen organisasi (X3) dapat diterima.

Hasil analisis hipotesis kelima memberikan temuan bahwa organisasi pembelajaran berpengaruh langsung positif terhadap komitmen organisasi. dengan nilai koefisien korelasi sebesar 0,286 dan nilai koefisien jalur sebesar 0,239. Berdasarkan hasil penelitian yang sudah dilakukan dan diuji secara statistik dapat disimpulkan bahwa komitmen organisasi dosen di Universitas Pamulang dipengaruhi secara langsung positif oleh organisasi pembelajaran.

Berdasarkan pembahasan di atas, kinerja dosen di Universitas Pamulang, Tangerang Selatan dapat ditingkatkan melalui kepemimpinan transformasional, dan kinerja dosen juga dapat ditingkatkan dengan mengembangkan organisasi pembelajaran. Meningkatnya kinerja dosen juga dipengaruhi oleh komitmen organisasi dari para dosen sehingga lebih percaya dan loyalitasnya terhadap Universitas Pamulang tinggi.

\section{KESIMPULAN}

Berdasarkan analisis statistik yang dilakukan, diperoleh temuan penelitian sebagai berikut : Kepemimpinan transformasional berpengaruh langsung positif terhadap kinerja. Organisasi pembelajaran berpengaruh langsung positif terhadap kinerja. Komitmen organisasi berpengaruh langsung positif terhadap kinerja. Kepemimpinan transformasional berpengaruh langsung positif terhadap komitmen organisasi pegawai.

Organisasi pembelajaran berpengaruh langsung positif terhadap komitmen organisasi. Berdasarkan temuan-temuan di atas, maka dapat disimpulkan bahwa kinerja dosen di Universitas Pamulang, Tangerang Selatan dapat dipengaruhi secara langsung oleh kepemimpinan transformasional, organisasi pembelajaran dan komitmen organisasi.

\section{DAFTAR PUSTAKA}

[1] Colquittt, Jason A., Jeffery A. Lepine dan Michael J. Wesson. Organizational Behavior: Improving Performance and Commitment in the Workplace. Boston: McGraw Hill, 2011.

[2] Djamaludin Ancok, Psikologi Kepemimpinan dan Inovasi, Erlangga, Jakarta 2012.

[3] Isao Kato \& Art Smalley. Toyota Kaizen Methods. By Taylor and Francis Group, LLC All rights reserved., 2011.

[4] Ivanka Menken, Organizational Behavior and Leadership Management Essentials, The Art of Service at: http://www.amazon.com,

[5] Jenifer M. George, Gareth $\mathrm{R}$ Jones, Understanding and Managing Organizational Behavior, by Pearson Education, Inc Publishing as Prentice Hall, One Lake Street, New Jersey, 2012

[6] Marquardt, J Michael, Building the Learning Organization, Press, Inc, 3803 East Bayshore Road, Palo Alto, 2002. 
[7] Senge, Peter M., The Fifth Discipline (The Art and Practice of The Learning Organization), Doubleday Dell Publishing Group, 1990.

[8] Undang-Undang Republik Indonesia Nomor 14 Tahun 2005. Tentang Guru dan Dosen, dan Peraturan Mendiknas Nomor 11 Tahun 2005 Beserta Penjelasannya. 2006. Penerbit Citra Umbara, Bandung, 2006.

[9] Yukl, G. Managerial Leadership: A Review of Theory and Research. Journal of Management, Vol. 15, No. 2, 1989. 